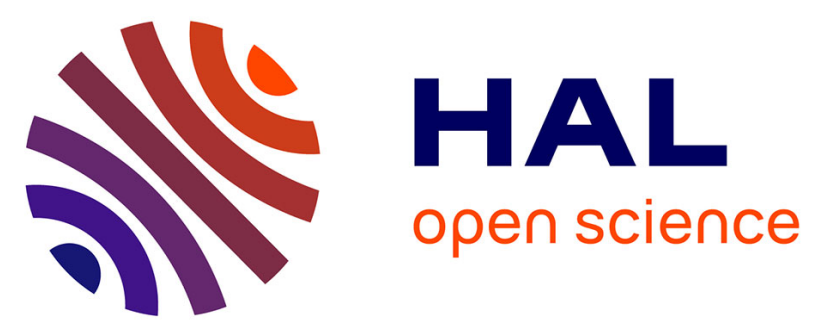

\title{
AB0014 Nanoparticles as MRI Contrast Agent for Early Diagnosis of RA: Effects of Amino-PVA-Coated SPIONS on CD4+ T Cell Activity
}

C. Strehl, Lionel Maurizi, S. Hermann, T. Häupl, H. Hofmann, F. Buttgereit, T. Gaber

\section{To cite this version:}

C. Strehl, Lionel Maurizi, S. Hermann, T. Häupl, H. Hofmann, et al.. AB0014 Nanoparticles as MRI Contrast Agent for Early Diagnosis of RA: Effects of Amino-PVA-Coated SPIONS on CD4+ T Cell Activity. Annals of the Rheumatic Diseases, 2016, 75 (Suppl 2), pp.901.3-901. 10.1136/annrheumdis2016-eular.2244 . hal-02163540

\section{HAL Id: hal-02163540 \\ https://hal.science/hal-02163540}

Submitted on 11 Mar 2021

HAL is a multi-disciplinary open access archive for the deposit and dissemination of scientific research documents, whether they are published or not. The documents may come from teaching and research institutions in France or abroad, or from public or private research centers.
L'archive ouverte pluridisciplinaire HAL, est destinée au dépôt et à la diffusion de documents scientifiques de niveau recherche, publiés ou non, émanant des établissements d'enseignement et de recherche français ou étrangers, des laboratoires publics ou privés. 


\section{AB0012 GENETIC SIGNATURES IN RHEUMATOID ARTHRITIS: CHANGES UPON ANTI-TNF THERAPY AND ASSOCIATION WITH RESPONSE TO BIOLOGICAL TREATMENT}

S. Poliska ${ }^{1}$, E. Végh ${ }^{2}$, A. Váncsa ${ }^{2}$, S. Szamosi ${ }^{2}$, M. Csumita ${ }^{1}$, G. Zahuczky ${ }^{3}$, G. Szücs ${ }^{2}$, S. Szántó ${ }^{2}$, L. Nagy ${ }^{4}$, Z. Szekanecz ${ }^{2}{ }^{1}$ Department of Biochemistry and Molecular Biology; ${ }^{2}$ Department of Rheumatology, University of Debrecen, Faculty of Medicine; ${ }^{3} x$, UD-Genomed Ltd, Debrecen, Hungary; ${ }^{4} x$, Sanford Burnham Medical Discovery Institute, Lake Nona, FL, United States

Background: Genetic signatures may be involved in the pathogenesis of rheumatoid arthritis (RA) and ankylosing spondylitis (AS). In addition, such genetic patterns may change overtime upon treatment with anti-TNF biologics. With respect to pharmacogenomics, pre-treatment genomics may predict response or non-response to biological therapy.

Objectives: In the present study, we wished to determine gene expression changes due to anti-TNF therapy. Furthermore, we wished to study associations between baseline genetic signature and response to TNF blockade.

Methods: Altogether $23 \mathrm{RA}$ and 17 AS patients were recruited for the study. Among RA patients, 10 received certolizumab pegol (CZP), and 13 etanercept (ETN). All AS patients were treated with ETN. Gene expression analysis using Affymetrix microarray and PrimeView array was performed at baseline and after 2 weeks of treatment. EULAR response criteria were used to differentiate responders (R) from non-responders (NR) after 12 weeks of treatment using GeneSpring software. Principal Component Analysis (PCA) was also performed. Changes in gene expression patterns were also determined between baseline and 2 weeks.

Results: In the CZP-treated RA group, 4 patients were R and 6 were NR. Altogether 453 genes showed significantly differential expression between $\mathrm{N}$ and NR. In the RA-ETN group, 10 patients were $R$, and 3 were NR. Here, 836 genes exerted differential expression. When a CZP- and ETN-treated patients, were pooled, 165 genes separated R from NR. In the AS population, 14 patients were $R$ and 3 were NR. 177 genes differentiated between R and NR. When changes in gene expression patterns from baseline to week 2 were determined, in the RA-CZP, RA-ETN, RA-all and AS groups 370, 79, 24 and 76 genes showed significant changes in expression.

Conclusions: Using microarray, genetic signatures may differentiate RA patients responding or not responding to anti-TNF therapy. Furthermore, a large set of genes show differential expression before versus 2 weeks after biologic treatment. Disclosure of Interest: None declared DOI: 10.1136/annrheumdis-2016-eular.2686

\section{Adaptive immunity ( $T$ cells and $B$ cells) in rheumatic diseases}

\section{AB0013 GLOMERULAR IL-4 SIGNALING MEDIATES FOOT PROCESS EFFACEMENT AND PROTEINURIA IN NEPHROTIC SYNDROMES}

A.H. Kim ${ }^{1}$, S. Akilesh ${ }^{2}$, A. Koziell ${ }^{3}$, B. Saunders ${ }^{4}$, S. Jain ${ }^{5}$, J. Hodgin ${ }^{6}$, B. Zinselmeyer ${ }^{4}$, T. Stappenback ${ }^{4}$, J. Miner ${ }^{5}$, A. Shaw ${ }^{7} .{ }^{1}$ Rheumatology, Washington University School of Medicine, Saint Louis, MO; ${ }^{2}$ Pathology, University of Washington, Seattle, WA, United States: ${ }^{3}$ Experimental Immunobiology, King's College, London, United Kingdom: ${ }^{4}$ Pathology and Immunology; ${ }^{5}$ Renal, Washington University School of Medicine, Saint Louis, MO; ${ }^{6}$ Pathology, University of Michigan, Ann Arbor, MI; ${ }^{7}$ Genentech, Inc., South San Francisco, CA, United States

Background: Podocyte foot process effacement is a feature of proteinuria, thought to be a stereotyped response of the podocyte to injury. The stimulus for podocyte injury and foot process effacement is unknown, although changes in the actin cytoskeleton has been implicated. B cell depletion therapies have demonstrated efficacy in some patients with proteinuria including those with minimal change disease. Since pathogenic antibodies are not causative, we hypothesized that a B cell derived cytokine might be capable of directly inducing podocyte injury and foot process effacement.

Objectives: Develop a B cell model of proteinuria in mice, and identify glomerulopathic cytokines derived from $B$ cells.

Methods: B cell model antigen model hen egg lysozyme (HEL) was biotinylated, complexed to avidin and injected into mice. HEL-specific B cells were adoptively transferred and proteinuria assessed. Two-photon microscopy was performed in vibrotomed kidneys following transfer of CFSE-labeled HEL-specific B cells with or without HEL antigen injection. Cultured podocyte membrane ruffling was assessed with DIC videomicroscopy. IL-4 expression in mice was achieved by hydrodynamically injecting murine IL-4 in the piggyBac vector system. Human kidney biopsies were assessed for phospho-STAT6 by immunohistochemistry. Results: We identified IL-4 as a B cell derived cytokine capable of stimulating podocyte actin rearrangement. Using a novel model of B cell induced proteinuria, B cells polarized to secrete IL-4 upon activation with HEL induced proteinuria without antibody or complement deposition. Using two-photon microscopy, we observed an accumulation of HEL-specific B cells within glomeruli containing HEL antigen.

To confirm the glomerulopathic properties of IL-4, we overexpressed IL-4 in mice and found this was sufficient to induce foot process effacement and proteinuria. Inhibition of IL-4 signaling with a JAK $1 / 3$ inhibitor markedly reduced proteinuria in these IL-4 overexpressing mice. Finally, a subset of patients (31\%) with steroid-sensitive nephrotic syndrome possessed glomerular STAT6 activation. Conclusions: These findings suggest a potential explanation for the utility of immunosuppression and more targeted anti-B cell therapy with rituximab in the treatment of steroid-sensitive nephrotic syndromes. These results support the role of IL-4 in human nephrotic syndromes and represents a novel therapeutic target.

Disclosure of Interest: A. Kim Grant/research support from: Rheumatology Research Foundation, Kypha Inc., S. Akilesh: None declared, A. Koziell: None declared, B. Saunders: None declared, S. Jain Grant/research support from: NIDDK/NIH, J. Hodgin Grant/research support from: NephCure/American Society of Nephrology, B. Zinselmeyer: None declared, T. Stappenback: None declared, J. Miner Grant/research support from: NIDDK/NIH, A. Shaw Employee of: Genentech, Inc.

DOI: 10.1136/annrheumdis-2016-eular.4376

\section{AB0014 NANOPARTICLES AS MRI CONTRAST AGENT FOR EARLY DIAGNOSIS OF RA: EFFECTS OF AMINO-PVA-COATED SPIONS ON CD4+ T CELL ACTIVITY}

C. Strehl ${ }^{1,2}$, L. Maurizi ${ }^{3}$, S. Hermann ${ }^{1}$, T. Häupl ${ }^{1}$, H. Hofmann ${ }^{3}$, F. Buttgereit ${ }^{1}$, T. Gaber ${ }^{1,2} .{ }^{1}$ Department of Rheumatology and Clinical Immunology, Charité University Medicine; ${ }^{2}$ German Rheumatism Research Centre (DRFZ), Berlin, Germany; ${ }^{3}$ Institute of Materials Powder Technology Laboratory, École polytechnique fédérale de Lausanne EPFL, Lausanne, Switzerland

Background: In medical applications nanotechnology provides new opportunities for diagnostic and therapeutic interventions in a variety of human diseases. Superparamagnetic iron oxide nanoparticles (SPION) are used as high-sensitive enhancer for magnetic resonance imaging, where they represent a promising too for early diagnosis of destructive diseases such as rheumatoid arthritis (RA) and osteoarthritis (OA).

However, safety aspects still represent crucial problems for the further development of nanotechnology based products. Therefore, the focus of our work here was to identify more in detail putative unwanted effects of amino-polyvinyl alcohol-coated (a-PVA) SPION on human immune cell functions.

Objectives: Since we could demonstrate in former studies that professional phagocytes are activated by a-PVA-SPION, we here focused on the influence of these nanoparticles on human $T$ helper cell activity.

Methods: PBMCs were isolated from blood samples obtained from healthy donors $(H D, n \geq 9)$ or patients suffering from RA $(n \geq 11)$. Primary human CD4 positive $T$ cells were separated via MACS-Sort and incubated with the mitogen PHA-L $(5 \mu \mathrm{g} / \mathrm{ml})$ and/or varying doses of a-PVA-SPION $(1 \mu \mathrm{g} / \mathrm{ml}, 10 \mu \mathrm{g} / \mathrm{ml}$, and $100 \mu \mathrm{g} / \mathrm{ml}$ ) or left untreated for $20 \mathrm{~h}$ (analysis of caspase-3/7-activity, intracellular ATP content and CD25 expression) or $72 \mathrm{~h}$ (analysis of proliferation and CD25 expression). Cells were incubated under either normoxia (app. 18\%O2) or hypoxia $(1 \% \mathrm{O})$ in order to mimic conditions found in the circulation and in the inflamed joint, respectively.

Results: We observed for PHA-L/a-PVA-SPION co-stimulated T cells from HD a decrease in cell count (all $p<0.05)$ whereas the caspase-3/7-activity is increased (all $\mathrm{p}<0.05$ ) in these samples, as expected. Although, we observed that $\mathrm{T}$ cells from RA patients are more susceptible to low-dose a-PVA-SPION-induced apoptosis than T cells from HD $(p<0.05)$, in both groups a-PVA-SPION do not activate CD4+ $\mathrm{T}$ cells per se and do not influence mitogen-mediated $\mathrm{T}$ cells activation with regard to CD25 expression and cell proliferation. Nevertheless, we were able to demonstrate that CD4+ T cells obtained from RA patients and healthy subjects differ in their response to mitogen stimulation and oxygen availability. Conclusions: PVA-SPION at concentrations up to $100 \mu \mathrm{g} / \mathrm{ml}$ do neither activate nor significantly influence mitogen-stimulated CD4+ T cells activation and have negligible influence on $\mathrm{T}$ cells apoptosis.

Disclosure of Interest: None declared

DOI: 10.1136/annrheumdis-2016-eular.2244

\section{AB0015 EVALUATING THE EFFECT OF ANTI-TNF, ANTI-IL6R AND ANTI-CTLA4 ON ACPA ISOTYPES IN PATIENTS WITH RHEUMATOID ARTHRITIS}

D. Hernandez-Flórez, T. del Río, J. Nieto, J. Ovalles, J. Martínez, B. Serrano, C. Mata, C. Gonzalez, I. Monteagudo, J. Lopez-Longo, E. Naredo, L. Valor. Rheumatology, Hospital General Universitario Gregorio Marañón, Madrid, Spain

Background: B-cell depletion therapy decreases autoantibodies formation as rheumatoid factor and anti-citrullinated protein antibodies (ACPA). Other therapeutic targets (TT) such as anti-TNF (tumor necrosis factor), anti-IL-6R (interleukin-6 receptor) and anti-CTL4A (cytotoxic T-lymphocyte antigen-4) modulate the B-cells proliferation/maturation and indirectly the production of autoantibodies. ACPA titers provide us information about disease activity and may be critical for inducing clinical remission in rheumatoid arthritis (RA) patients.

Objectives: To evaluate the impact of the therapeutic targets: anti-TNF; anti-IL6R and anti-CTLA4 on ACPA titers in RA patients.

Methods: In this longitudinal study we selected ACPA positive patients naïve to 